\title{
MAGNETIC RESONANCE IMAGING GUIDED DIAGNOSIS OF SUBUNGUAL GLOMUS TUMOUR IN TWO YOUNG FEMALES
}

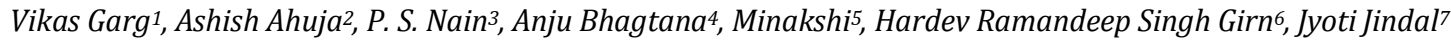 \\ ${ }^{1}$ Associate Professor, Department of Medicine, Dayanand Medical College \& Hospital, Ludhiana. \\ ${ }^{2}$ Associate Professor, Department of Surgery, Dayanand Medical College \& Hospital, Ludhiana. \\ 3 Professor, Department of Surgery, Dayanand Medical College \& Hospital, Ludhiana. \\ 4 Senior Resident, Department of Surgery, Dayanand Medical College \& Hospital, Ludhiana. \\ ${ }_{5}^{5}$ Associate Professor, Department of Nursing, Dayanand Medical College \& Hospital, Ludhiana. \\ ${ }^{6}$ Assistant Professor, Department of Surgery, Dayanand Medical College \& Hospital, Ludhiana. \\ ${ }^{7}$ Resident, Department of Medicine, Dayanand Medical College \& Hospital, Ludhiana.
}

\section{ABSTRACT}

Glomus tumours are uncommon benign hamartomas arising from glomus body. We report two cases of subungual glomus tumour, who had presented because of intense pain in fingertip. Both were diagnosed with Magnetic Resonance Imaging (MRI). They were treated with excision biopsy and histopathology revealed subungual glomus tumour.

\section{KEYWORDS}

Glomus Tumour, MRI, Subungual.

HOW TO CITE THIS ARTICLE: Garg V, Ahuja A, Nain PS, et al. Magnetic resonance imaging guided diagnosis of subungual glomus tumour in two young females. J. Evolution Med. Dent. Sci. 2016;5(40):2485-2487, DOI: 10.14260/jemds/2016/579

\section{INTRODUCTION}

Glomus tumours are uncommon benign hamartomas arising from the arterial end of the glomus body. They often present early in the subungual stage because of intense pain. Two female patients with subungual glomus tumour are reported here. There was intense pain associated with this tumour in the fingertip. Both the patients were referred to various departments for treatment, even to psychiatry. Thorough history, physical examination and Magnetic Resonance Imaging (MRI) findings helped diagnose the existence of a mass at the subungual area of the digit. Both patients were treated with excision biopsy and the histopathological result showed glomus tumour. Tumours were resected by transungual approach, leaving a 5-mm wide margin. There was no recurrence after 1-year follow-up in both instances.

\section{CASE REPORTS}

\section{Case 1}

A 32-year-old nursing tutor presented with painful little finger tip since one year. She had practically visited all departments in search of cure. She had been to orthopaedics, surgery, dermatology, physiotherapy and psychiatry departments. MRI helped in diagnosing a mass lesion in subungual region of little finger (Figure 1, 2). Transungual surgical approach revealed shiny encapsulated tumour, which was excised en bloc and biopsy confirmed glomus tumour (Figure 3, 4) section showing tumour composed of variable sized vascular channels surrounded by cells with abundant eosinophilic cytoplasm and monomorphic nuclei (H\&E, 100X). She has been followed for 1 year with no recurrence of symptoms.

Financial or Other, Competing Interest: None.

Submission 30-03-2016, Peer Review 29-04-2016,

Acceptance 05-05-2016, Published 19-05-2016.

Corresponding Author:

Dr. Ashish Ahuja,

\#132/1,

Rani Jhansi Road, Civil Lines,

Ludhiana-141001,

Punjab.

E-mail: drahuja17@gmail.com

DOI: $10.14260 /$ jemds $/ 2016 / 579$

\section{Case 2}

A 32-year-old female from a small town presented with a 2year history of excruciating spontaneous episodic shooting pain over the terminal digit of the right index finger. The pain lasted for few seconds at a time, but increased in intensity. The pain was temporarily relieved with analgesics. Examination did not reveal any swelling and X-ray did not show any abnormality. She had consulted local doctors, surgeons, orthopaedics and even psychiatrist. MRI showed a mass lesion in right index finger. Transungual surgical approach revealed a 2-mm diameter pearly, shiny, encapsulated swelling that was removed with a 5-mm wide margin. Histopathological examination confirmed the clinical and perioperative diagnosis of glomus tumour (Figure 5; High power view of tumour cells surrounding the vascular channel (arrow) (H\&E, $400 \mathrm{X})$ ). She has been free of any symptoms and sigh of recurrence in one year of follow-up.

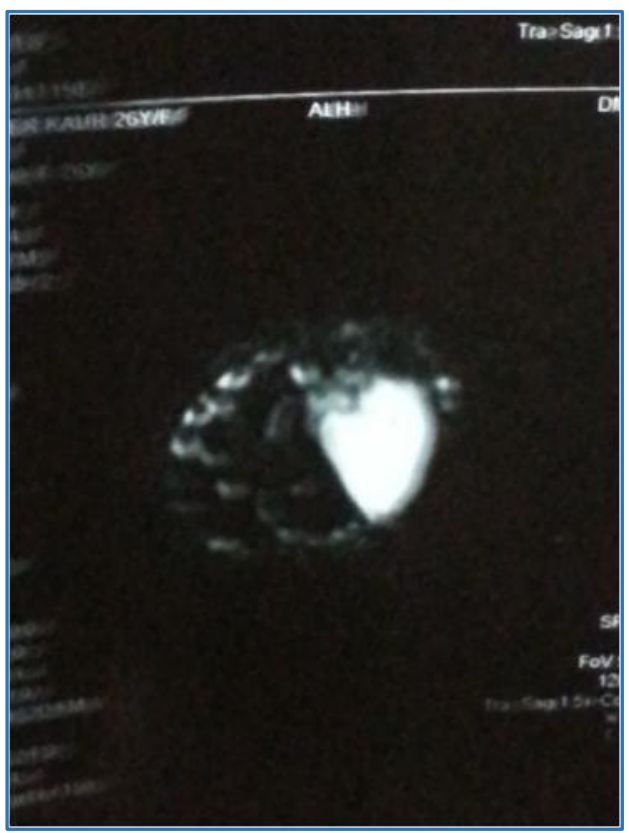

Fig. 1: MRI showing Glomus Tumour 


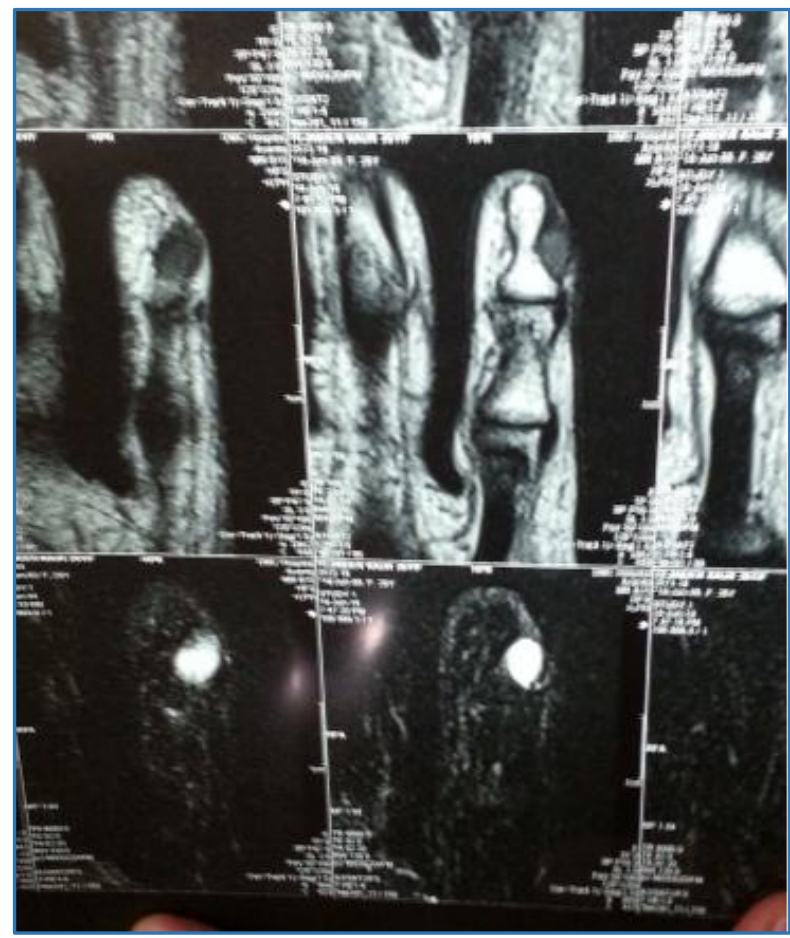

Fig. 2: MRI showing Glomus Tumour

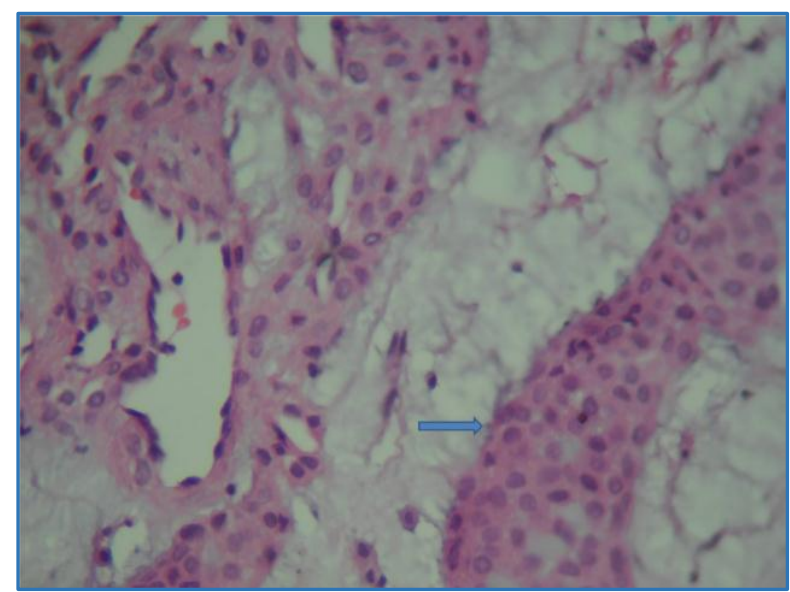

Fig. 3: Section showing Tumour Composed of Variable Sized Vascular Channels Surrounded by Cells with Abundant Eosinophilic Cytoplasm and Monomorphic Nuclei (H\&E, 100X)

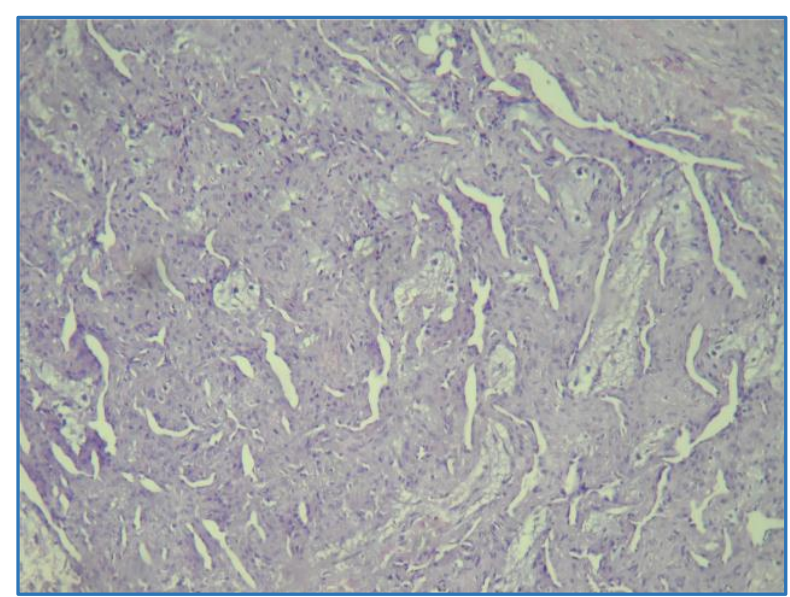

Fig. 4: Section showing Tumour Composed of Variable Sized Vascular Channels Surrounded by Cells with Abundant Eosinophilic Cytoplasm and Monomorphic Nuclei (H\&E, 100X)

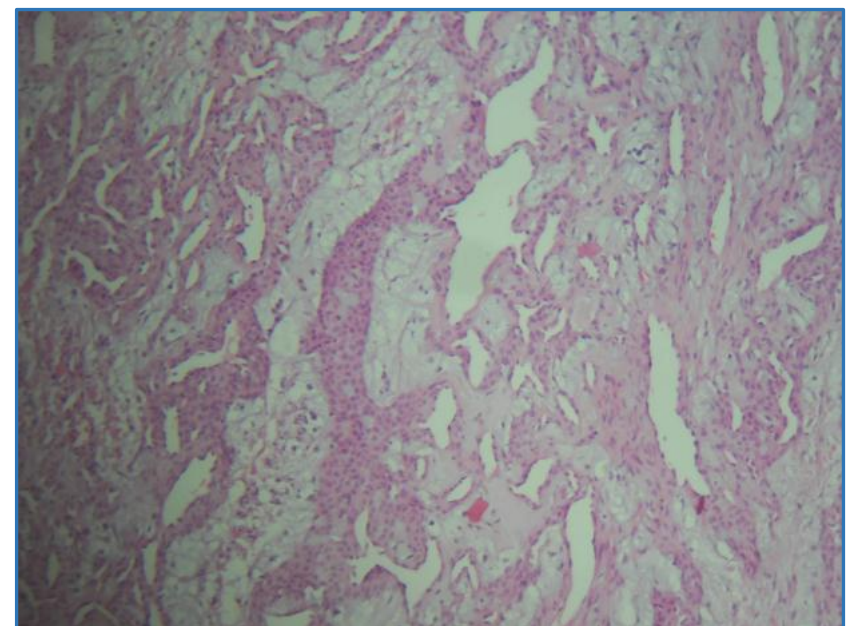

Fig. 5: High Power View of Tumour Cells Surrounding the Vascular Channel (Arrow) (H\&E, 400X)

\section{DISCUSSION}

Subungual glomus tumours are extremely painful lesions leading to early presentation. Typically, solitary lesions are characterized by a reddish-purple discoloration of the lesion, paroxysmal pain, tenderness and cold-sensitivity. The lesion is usually located on the extremities, especially the nail bed as seen in both of our patients, but may occur on other parts of the body. ${ }^{1}$ The solitary subungual tumours are common in females. Sometimes the pain can be of severe nature, leading to disuse atrophy of the limb. Multiple lesions are more common in males.

Surgery is a treatment of choice with transungual approach with adequate margin. For multiple lesions, excision may be more difficult because of their poor circumscription and the large number of lesions. Thus only symptomatic glomus tumours are excised surgically. These subungual lesions are small and localization with MRI is required for total excision; otherwise, multiple procedures may be required in some patients. ${ }^{2,3}$ To avoid recurrence of symptoms like pain, it is important that the accurate preoperative localization of the tumour and a complete extirpation should be performed. Thus, MRI is the investigation of choice for localization and diagnosis of subungual glomus tumour. Transungual approach can lead to nail deformity, thus periungual approach has been advocated in tumour in peripheral locations and transungual approach for central regions with meticulous repair of nail bed by plastic surgery. ${ }^{4}$ We had localised the lesions preoperatively; being in the central region thus had preferred the transungual approach with nail bed reconstruction. In both cases glomus tumour was completely excised with adequate margin; no recurrence occurred in one year of follow-up period. Interestingly, there is an earlier case report of glomus tumour leading to disuse atrophy. 5

Glomus tumours arise both from glomus cells and extracutaneous sites that do not contain glomus cells. Glomus tumours in intra-oral location such as palate was reported by Geragty. ${ }^{6}$ Some glomus tumours with unusual clinical features such as large size, deep soft tissue or visceral location, infiltrative growth pattern or multicentricity.7,8,9 Gould reported a few case reports of clinically malignant glomus tumours. ${ }^{7}$ Routine laboratory investigations do not help in diagnosis of glomus tumour. Magnetic Resonance Imaging (MRI) is the gold standard to detect glomus tumours with highresolution MRI helping in assessing tumour characteristics 
more accurately.10,11,12 Magnetic resonance imaging shows a well-circumscribed mass, which is isointense to the dermis of the nail bed on the T1-weighted image and hyperintense on the T2-weighted image. ${ }^{13}$ Hatori had studied the expression of CD-34 in glomus tumours. ${ }^{14}$ Histologically, this is a wellcircumscribed lesion characterized by solid aggregates of glomus cells around small capillary sized vessels in a myxoid or hyalinised stroma. The glomus cell is round, regular shaped with a sharply punched out rounded nucleus. The tumour cells reveal immunopositivity for vimentin, smooth muscle actin and muscle specific actin in the cytoplasm. The cells do not stain with endothelial markers. Desmin is occasionally only focally positive.

\section{REFERENCES}

1. Murthy PS, Rajagopal R, Kar PK, et al. Two cases of subungual glomus tumour. Indian J Dermatol Venereol Leprol 2006;72(1):47-9.

2. Dawber RP, Baran R. Disorders of nails. In: Champion RH, Burton JL, Ebling FJG, editors. Rook/Wilkinson/Ebling Textbook of dermatology. Oxford: Blackwell Science; 1992; $5^{\text {th }}$ ed:2497-532.

3. Heys SD, Brittened J, Atkinson P, et al. Glomus tumour: an analysis of 43 patients and review of the literature. $\mathrm{Br} \mathrm{J}$ Surg 1992;79(4):345-7.

4. Takata H, Ikuta $Y$, Ishida 0 , et al. Treatment of subungual glomus tumour. Hand Surg 2001;6(1):25-7.

5. Garg BR, Lal Sardari. Glomus tumours with disuse atrophy. Indian J Dermatol Venereol Leprol 1973;39(6):270-1.
6. Geraghty JM, Thomas RW, Robertson JM, et al. Glomus tumour of the palate: case report and review of the literature. Br J Oral Maxillofac Surg 1992;30(6):398-400.

7. Gould EW, Manivel JC, Albores-Saavedra J, et al. Locally infiltrative glomus tumours and gloman-giosarcomas: a clinical, ultrastructural and immune-histochemical study. Cancer 1990;65:310-8.

8. Kiyosawa T, Umebayashi Y, Nakayama Y, et al. Hereditary multiple glomus tumours involving glans penis. A case report and review of literature. Dermatol Surg 1995;21(10):895-9.

9. Lumley JS, Stansfiels AG. Infiltrating glomus tumour of lower limb. BMJ 1972;1(5798):484-5.

10. Drape JL, Idy-Peretti I, Goettmann S, et al. Standard and high resolution magnetic resonance imaging of glomus tumours of toes and fingertips. J Am Acad Dermatol 1996;35(4):550-5.

11. Giele H. Hildreth's test is a reliable clinical sign for the diagnosis of glomus tumours. J Hand Surg 2002;27(2):157-8.

12. Bhaskaranand K, Navadgi BC. Glomus tumour of the hand. J Hand Surg 2002;27(3):229-31.

13. Takemura N, Fujii N, Tanaka T. Subungal glomus tumour diagnosis based on imaging. J Dermatol 2006;33(6):38993.

14. Hatori M, Aiba S, Kato M, et al. Expression of CD 34 in glomus tumours. Tohoku J Exp Med 1997;182(3):241-7. 